\title{
Assessment of the Interactive Effect of the Use of 1-Methylcyclopropene and Cultivars on the Nutritional Value of Broccoli during Storage
}

\author{
Dorota Wichrowska $^{1, *(\mathbb{D})}$, Wojciech Kozera ${ }^{2} \mathbb{D}$, Tomasz Knapowski ${ }^{2} \mathbb{D}$, Piotr Prus ${ }^{3}$ and Anna Ligocka $^{1}(\mathbb{D}$ \\ 1 Department of Microbiology and Food Technology, Faculty of Agriculture and Biotechnology, \\ Bydgoszcz University of Science and Technology, Kaliskiego 7 Str., 85-796 Bydgoszcz, Poland; \\ ligocka@pbs.edu.pl \\ 2 Laboratory of Agricultural Chemistry, Department of Biogeochemistry and Soil Science, Faculty of \\ Agriculture and Biotechnology, Bydgoszcz University of Science and Technology, Seminaryjna 5 Str., \\ 85-326 Bydgoszcz, Poland; kozera@pbs.edu.pl (W.K.); knap@pbs.edu.pl (T.K.) \\ 3 Laboratory of Economics and Agribusiness Advisory, Department of Agronomy, Faculty of Agriculture \\ and Biotechnology, Bydgoszcz University of Science and Technology, Fordońska 430 Str., \\ 85-790 Bydgoszcz, Poland; piotr.prus@pbs.edu.pl \\ * Correspondence: wichrowska@pbs.edu.pl; Tel.: +48-52-374-9320
}

check for updates

Citation: Wichrowska, D.; Kozera, W.; Knapowski, T.; Prus, P.; Ligocka, A. Assessment of the Interactive Effect of the Use of

1-Methylcyclopropene and Cultivars on the Nutritional Value of Broccoli during Storage. Agronomy 2021, 11, 2575. https://doi.org/10.3390/ agronomy 11122575

Academic Editor: Rajko Vidrih

Received: 24 November 2021 Accepted: 15 December 2021 Published: 17 December 2021

Publisher's Note: MDPI stays neutral with regard to jurisdictional claims in published maps and institutional affiliations.

Copyright: (c) 2021 by the authors. Licensee MDPI, Basel, Switzerland. This article is an open access article distributed under the terms and conditions of the Creative Commons Attribution (CC BY) license (https:// creativecommons.org/licenses/by/ $4.0 /)$.

\begin{abstract}
Broccoli is a short-term fresh storage vegetable; it most often goes to the processing plant where it is frozen or cold-stored. 1-methylcyclopropene gas (1-MCP) can be used to extend broccoli's shelf life. The aim of the study was to investigate the effect of the genetic cultivar determinants, the use of 1-MCP and the storage time on the weight loss as well as the content of nutrients and harmful compounds in cultivars: 'Bay Meadows', 'Monaco', 'Naxos' and 'Vicario'. The cultivars selected for the study differed significantly in terms of the traits after harvest and storage, and the differences were also conditioned by the interaction of the genetic factor and 1-MCP used, especially within 30 days after harvest. Of the broccoli cultivars, 'Monaco' demonstrated the lowest weight loss during storage, the highest content of dry weight, total sugars, vitamin $C$, both after harvest and after storage, in the samples treated with 1-methylcycloprepene after harvest. In turn, 'Vicario' lost most weight after storage and broccoli florets treated with 1-MCP have lost less weight. The highest amounts of nitrates and nitrites, both after harvest and after storage, were found in 'Monaco'; however, the differences, as compared with the other cultivars, were significant, yet relatively low. The lowest compactness of the florets was recorded, and hence the lowest commercial value (basically unmarketable), for 'Naxos', 'Monaco' and 'Vicario' cultivars after 30 days of storage without the use of 1-MCP. However, due to the use of $1-\mathrm{MCP}$ and low temperature $\left(4^{\circ} \mathrm{C}\right)$, the commercial value of those broccoli cultivars was satisfactory.
\end{abstract}

Keywords: 1-methylcyclopropen; cultivar; weight loss; dry weight; total and reducing sugars; protein; ascorbic acid; nitrates; nitrites; sensory analysis

\section{Introduction}

The set of traits of the vegetables intended for storage determines their storage value. Most important of all is the storage durability, i.e., a set of genetically-fixed traits in the breeding process, determining the differences in the morphological, anatomical and chemical composition of individual species or even cultivars of vegetables. The maturity and quality of vegetables at the start of storage also affects the shelf life of the vegetables [1]. Broccoli (Brassica oleracea L.) is a vegetable that is particularly unstable when stored due to its high respiration rates and high water loss [1]. Broccoli can be classified as climacteric since florets became yellow as respiration and ethylene production increase [2]. As claimed by Costa et al. [3], as it is the case in many other products, broccoli floret aging is due to ethylene production. 
Broccoli florets, when adequately harvested, must be chilled to a low temperature immediately after harvesting in order to inhibit vital processes and to maintain good firmness and freshness during further storage. The concentration of ethylene in the atmosphere of stored vegetables, in the order of a $0.5 \mathrm{ppm}$, accelerates aging and thus shortens the storage period [2]. The development of technologies facilitating longer-term preservation of the freshness, attractiveness and nutritional value of products at the base of the food pyramid, i.e., in seasonal vegetables, is the subject of interest of many scientific and research centers. In addition, shelf life should allow a safe distribution, sale and storage of food by the consumer.

Poland comes fourth in terms of broccoli production in Europe, behind Spain, Italy and Great Britain. The vegetable is produced for the domestic market and to be exported, mainly to Germany, England, the Czech Republic, Slovakia and Hungary [4]. Broccoli is a relatively unstable vegetable when fresh. It is harvested when unripe, however, unfortunately, its florets deteriorate quickly after harvesting at ambient temperature. Typically, broccoli arrives at the store 7-14 days after harvest and it is refrigerated until purchased or discarded. One of the visible signs of aging in broccoli is florets yellowing, accompanied by a degradation of chlorophyll, protein and many other compounds affecting the sensory and nutritional quality. Additionally, there can be a significant loss of nutrients during this period, including important bioactive compounds such as ascorbic acid, glucosinolates, folic acid and sulforaphane (a molecule with a high biological activity against prostate cancer) [5-9]. Sugars are one of the basic nutrients of broccoli. They are a good source of energy: from $40 \%$ to $80 \%$ of the daily requirement. The sugar content depends on the cultivar, climate conditions, cultivation and storage [10]. Feng X. et al. [10] indicate that 1-MCP may delay the aging of broccoli florets, which in this study could be due to maintaining a higher sugar content by regulating sugar metabolism. Moreover, senescence is also connected to fast degradation of proteins. Proteins are catabolized early and lead to a decrease in photosynthetic activity [11]. In broccoli, the expression of several protease genes has been observed to increase in the course of aging [12]. Broccoli florets have a high concentration of ascorbic acid, although rapid degradation of this compound has been noted in the florets stored at ambient temperature after harvesting [13]. Procedures and the technologies for preserving the commercial and nutritional quality of broccoli have been studied, such as refrigeration [14], heat treatment [15], modified atmospheres [16], UV [17] and 1-MCP [18,19]. Acute toxicity, mutagenicity and product chemistry investigated for SmartFresh formulation indicate a favorable toxicology profile [20]. In addition, 1-MCP has a non-toxic mode of action, is applied at extremely low ppb dose levels and has no measurable residue in food commodities [20]. The compound concentration required to promote inhibition of the ethylene action varies according to the species, cultivar, maturation stage, temperature and exposure time, and the production of new ethylene receptors on the cell membranes [21]. In the European Union countries, 1-MCP is included in Directive 91/414/EEC (2005) [22] as an ingredient that could be used for fruits and vegetables. 1-MCP is thought to interact with ethylene receptors and, thereby, it prevents ethylene-dependent responses [20,21,23-25]. The use of cyclopropenes to inhibit ethylene action was patented by Sisler and Blankenship [23]. A commercial breakthrough in 1-MCP application technology resulted from the formulation of 1-MCP as a stable powder in which it is complexed with $\gamma$-cyclodextrin, so that 1-MCP is easily released as a gas when the powder is dissolved in water. The powder is mixed with distilled water and using the so-called SmartFresh generator, the active substance is released properly and spreads in the chamber. The procedure takes $24 \mathrm{~h}$ in a tightly closed chamber. Broccoli should be treated immediately after harvesting the florets. Since February 2008, SmartFresh has been registered in Poland for use in the apple storage process. Since June 2014, this registration has been extended to include plums, pears, broccoli, and Chinese and white cabbage. The most effective activity of 1-MCP is demonstrated at a concentration of 0.1 to $12 \mathrm{ppm}$ [1]. The influence of SmartFresh on selected vegetables and fruits has also been presented by others, including [26], where, in broccoli, 1-MCP reduced the intensity of respiration, 
yellowing and rotting. Climacteric and non-climacteric fruits and vegetables for which responses to 1-MCP were tested are presented in the sources available in Watkins and Miller [27].

Broccoli is very sensitive to ethylene and, as such, it should not be stored with fruits and vegetables releasing it in large amounts. In addition, ethylene causes a degradation of chlorophyll and accelerates vegetable maturing [28]. However, the durability of 1-MCP is influenced by, e.g., the species, the cultivar and the ethylene biosynthesis inducing method [29]. The knowledge about the reaction of cultivars to the use of technology with $1-\mathrm{MCP}$ will enhance the selection of storage conditions depending on the destination and further distribution of the raw materials, e.g., export.

There are few publications on the effect of 1-MCP on nutrients of broccoli cultivars chosen for research. Therefore, the aim of the study has been to investigate the interactive effect of 1-MCP and the genetic determinants of the cultivar on the nutritional value, as well as on the content of harmful compounds in broccoli.

\section{Materials and Methods}

\subsection{The Broccoli Production}

The research material was broccoli from a local producer from field crops located in the Kuyavian-Pomeranian Province $\left(53^{\circ} 00^{\prime} 34^{\prime \prime}\right.$ N $17^{\circ} 44^{\prime} 23^{\prime \prime}$ E), which has applied the standard recommended production practices, in accordance with the methodology of integrated broccoli production, approved under Art. 57 s. 2 point 2 of the Act of 8 March 2013 on plant protection products (Journal of Laws of 2015, item 547, as amended) by the Chief Inspector of Plant Health and Seed Inspection in Poland.

\subsection{The Broccoli Cultivars}

'Bay Meadows' is a cultivar with high tolerance to high temperatures. The ideal growing conditions are a continental climate with high temperatures and low soil moisture. The growing season for this cultivar is approximately 60-70 days. It has a strong root system and compact regularly-shaped florets. It shows high resistance to the formation of voids in the stems and to overgrowth of florets with leaves and discoloration. The advantages of this cultivar are a domed shape, a thick stem, leaves easy to remove from the stem. 'Bay Meadows' are mainly intended for the fresh market.

'Monaco' is especially recommended for cultivation for processing but also for the fresh market. Its characteristic features are compact, high-set florets and very short floret heads. It has small dark green buds. It is characterized by high vigor and considerable mass. The 'Monaco' cultivar does not show the ability to create side suckers. The growing season for this cultivar is $80-90$ days.

'Naxos' is a cultivar characterized by strong growth and root system. It demonstrates a compact and upright habit, which means that this cultivar can be cultivated in high density. It has no tendency to side shoots, and the wreath-forming leaves surrounding the florets protect against wind and direct contact with sunlight. The growing season for this cultivar is 65-75 days. It is intended for late spring and summer cultivation, and the appropriate harvest date is July and August. This cultivar is ideal for industry and the fresh market. 'Naxos' shows an apical meristem necrosis if the seedlings are not grown properly.

'Vicario' - this cultivar is characterized by a very high uniformity of the florets. The broccoli plants do not tend to overgrow, and no hollow chambers are formed in the stalks. The growing season for this cultivar is approximately 65 days. The weight of the roses varies from 300 to $500 \mathrm{~g}$. The cultivar is mainly intended for the fresh market.

\subsection{Harvest and Storage}

Four broccoli cultivars: 'Bay Meadows', 'Monaco', 'Naxos', 'Vicario' were harvested when their head diameter was 10 to $15 \mathrm{~cm}$. The harvest took about two hours per cultivar, and the transport time was about $45 \mathrm{~min}$ to the cold store from the field. Immediately after harvesting, the broccoli florets were chilled at $2{ }^{\circ} \mathrm{C}$ using forced cool air for $50 \mathrm{~min}$, and 
then placed in a refrigerator at $4{ }^{\circ} \mathrm{C}$ and $95 \%$ relative air humidity. The collected broccoli of similar weight was divided into two groups. In one of them, the broccoli was treated with the air (control), in the other, 1-MCP was applied in a concentration of $1 \mu \mathrm{L} \cdot \mathrm{L}^{-1}$ for $20 \mathrm{~h}$ in sealed containers. The research involved the use of SmartFresh by AgroFresh, Poland. There were 24 boxes in total ( 4 variants, 2 groups: treated and untreated in 3 replications).

Broccoli was sampled for analysis after 10, 20 and 30 days of storage in a chamber with temperature of $4{ }^{\circ} \mathrm{C}$ and relative air humidity of $98-99 \%$.

\subsection{Weight Loss}

Weight loss was calculated as the difference between the initial weight (after harvest) of 10 broccoli florets and after 10,20,30 days of storage and expressed as a percentage.

\subsection{Laboratory Analysis}

Laboratory analyses included the content of nutrients and health-promoting compounds: total sugars, reducing sugars, vitamin $C$, protein, dry matter, and harmful nitrates and nitrites.

\subsection{Determination of Dry Matter}

The dry matter content was determined according to the European Association for Potato Research (EAPR) [30]. Five broccoli florets were washed, dried and cut into cubes. Then they were homogenized in a laboratory mixer until homogenous pulp was obtained. About ten grams of the pulp was poured into a Petri dish and then heated at $60{ }^{\circ} \mathrm{C}$ for 15 $\mathrm{h}$; afterwards, the oven temperature was raised to $105^{\circ} \mathrm{C}$ for $3 \mathrm{~h}$ and then Petri dish with dry matter of broccoli florets was cooled down to room temperature in desiccators and weighed. The total dry matter was calculated according to the following formula:

$$
\mathrm{DM}=\mathrm{D} / \mathrm{M} \times 100
$$

where DM-dry matter (\%), D—weight of dry sample (g), W-weight of fresh sample (g).

\subsection{Determination of Sugars}

Carbohydrate analyses were made according to procedures in [31]. For a reducing sugar content assessment, ten grams of fresh material sample was placed in $250 \mathrm{~mL}$ bottle, $150 \mathrm{~mL}$ of distilled water was added and vigorously shaken. One milliliter of the filtrate was mixed with $3 \mathrm{~mL}$ of DNP (2,4-dinitrophenol) (Sigma-Aldrich, Darmstadt, Germany) reagent in a test tube and then heated in a water bath at $95{ }^{\circ} \mathrm{C}$ for $6 \mathrm{~min}$. Absorbance of the mixture was measured using the spectrophotometer at a wavelength of $600 \mathrm{~nm}$ using a Shimadzu UV-spectrophotometer, (Shimadzu, Kyoto, Japan). The reducing sugar content was estimated using the standard curve of glucose. The total soluble carbohydrate was determined after hydrolysis of sugars. After filtration, $40 \mathrm{~mL}$ of the filtrate was taken, a few drops of concentrated $\mathrm{HCl}$ (POCH Gliwice) were added. The samples were warmed up for $30 \mathrm{~min}$ in a water bath. After cooling, the mixture was neutralized using a few drops of concentrated $\mathrm{NaOH}$ (POCH Gliwice). Next, $1 \mathrm{~mL}$ of the filtrate was mixed with $3 \mathrm{~mL}$ of DNP (Sigma-Aldrich, Darmstadt, Germany) reagent and the procedure for determining the content of reducing sugars was followed.

\subsection{Determination of Ascorbic Acid}

The ascorbic acid content was assessed according to Kapur et al. [32]. Ten grams of fresh sample of broccoli were homogenized with $25 \mathrm{~mL}$ of metaphosphoric acid solution (Sigma-Aldrich) and quantitatively transferred into a $50 \mathrm{~mL}$ volumetric flask and gently shaken to homogenize the solution. Then it was diluted up to the mark with the metaphosphoric acid solution. The solution was filtered and centrifuged at $4000 \mathrm{rpm}$ for $15 \mathrm{~min}$, the supernatant solution was used for spectrophotometric determination (UV-1800, UV Spectrophotometer System, Japan) of ascorbic acid content in samples of different broccoli. Ascorbic acid is oxidized to dehydroascorbic acid by adding bromine water. After that, 
L-dehydroascorbic acid reacts with 2,4-DNPH (Sigma-Aldrich, Darmstadt, Germany) and produces an osazone, which, treated with $85 \% \mathrm{H}_{2} \mathrm{SO}_{4}$, forms a red-colored solution. A typical calibration plot was made and used to determine the concentration of ascorbic acid in the samples.

\subsection{Determination of Crude Protein}

The content of crude protein was determined by multiplication of total nitrogen by factor 6.25, with the Kjeldahl method using Büchi Labortechnik B-324 apparatus, after mineralization in concentrated sulphuric acid (VI). Total nitrogen was analysed according to the Dumas combustion method by LECO CN-2000 [33].

\subsection{Determination of Nitrates (V) and Nitrates (III)}

The contents of nitrates were determined directly after harvest and after 10, 20 and 30 days of storage using the ion-selective method [34]. A multi-purpose Elmetron CX-721 computer was used; it was equipped with a nitrate electrode, double junction reference electrode (the outer chamber was filled with $0.02 \mathrm{M}\left(\mathrm{NH}_{4}\right) 2 \mathrm{SO}_{4}$ solution (Merck, Darmstadt, Germany) and provided with a specific ion meter and a $\mathrm{pH} /$ millivolt $(\mathrm{mV})$ meter with a $0.1 \mathrm{mV}$ readability. Nitrates were extracted using a $\mathrm{KAl}\left(\mathrm{SO}_{4}\right)_{2}$ (Merck, Darmstadt, Germany) solution and potentiometrically assayed with an ion-selective electrode. Ten grams of fresh broccoli samples and $50 \mathrm{~cm}^{3} 1 \%$ of $\mathrm{KAl}\left(\mathrm{SO}_{4}\right)_{2}$ extracting solution were then mixed and shaken (IKA KS 130 BASIC, Aachen, Germany) for one hour. Subsequently, $10 \mathrm{~cm}^{3} \mathrm{Al}_{2}\left(\mathrm{SO}_{4}\right)_{3}$ was added (Acros Organics, USA) to it and shaken immediately before the analysis. The standard solutions were all conducted in the $0.025 \mathrm{M} \mathrm{Al}_{2}\left(\mathrm{SO}_{4}\right)_{3}$ background solution and de-ionized water was also used in the analytical research at each stage of the analysis. The total content of $\mathrm{NO}_{2}$ was determined after oxidation to $\mathrm{NO}_{3}$ in a previously prepared sample of the extract according to the method described above. An amount of $1 \mathrm{~cm}^{3}$ of $30 \% \mathrm{H}_{2} \mathrm{O}_{2}$ (Merck, Darmstadt, Germany) was added and the ion-metric potential was carefully measured after five minutes in order to facilitate the oxidation of $\mathrm{NO}_{2}$ to $\mathrm{NO}_{3}$.

\subsection{Organoleptic Assessment}

An organoleptic evaluation according to UNECE STANDARD FFV-48 [35] and own discriminants of sensory quality (color, compactness, rotting, taste and commercial value) was performed by a team of 10 persons trained in the basic methods of sensory analysis who checked for individual sensory sensitivity [36]. The classification of broccoli is presented in Table 1.

Table 1. Classification of broccoli [35].

\begin{tabular}{|c|c|}
\hline Broccoli in Class I & Broccoli in Class II \\
\hline $\begin{array}{l}\text { - } \quad \text { must be of good quality and have the } \\
\text { characteristics of the cultivar; } \\
\text { - } \quad \text { must be firm and compact; } \\
\text { - } \quad \text { fightly-grained; } \\
\text { - } \quad \text { buds must be fully closed; } \\
\text { - the floral stem must be sufficiently tender and free } \\
\text { of woodiness; } \\
\text { The following slight defects, however, may be } \\
\text { allowed, provided these do not affect the general } \\
\text { appearance of the produce, quality, maintaining the } \\
\text { quality and presentation in the package: } \\
\text { - } \quad \text { a slight defect in shape, a slight defect in coloring; } \\
\text { - leaves extending above the florets may be allowed } \\
\text { provided these are green, sound, fresh and tender. }\end{array}$ & $\begin{array}{l}\text { class II includes broccoli that does not } \\
\text { qualify for inclusion in class I but } \\
\text { satisfy the minimum requirements } \\
\text { specified above; } \\
\text { broccoli may be: slightly loose and } \\
\text { less compact, less tightly-grained; } \\
\text { buds must be practically closed; } \\
\text { the floral stem must be reasonably } \\
\text { tender, and may have a trace of } \\
\text { woodiness; } \\
\text { The following defects may be } \\
\text { allowed, provided broccoli retains its } \\
\text { essential characteristics as regards the } \\
\text { quality, maintaining the quality and } \\
\text { presentation in the package: } \\
\text { defects in shape defects in coloring } \\
\text { slight bruising and injury. }\end{array}$ \\
\hline
\end{tabular}




\subsection{Statistical Analysis}

The results were statistically analyzed by means of one factor analysis of variance after harvest where the factor was cultivar, and also a two-factor analysis of variance after storage, treating as variables the cultivar model and storage technology (use or not of 1-MCP). The results were statistically analyzed, an analysis of variance (ANOVA) of data from each experiment and the synthesis from three repetitions were made. The significance of differences was evaluated using the Tukey multiple confidence intervals for the significance level of $\alpha=0.05$. Calculations were made independently for each storage time using Statistica ${ }^{\circledR} 13.1$.

\section{Results}

\section{Weight Loss}

The broccoli cultivars selected for the study differed significantly in terms of weight loss. Significantly, the lowest loss of fresh weight was reported for 'Monaco', both after 10, 20 and 30 days of storage, the biggest losses were for 'Vicario', especially after 20 and 30 days of storage, and 'Bay Meadows' after 20 days of storage (Table 2).

Table 2. Weight loss (\%) after 10, 20, 30 days of storage depending on the cultivar and storage technology (mean for cultivars and storage technology).

\begin{tabular}{|c|c|c|c|c|}
\hline \multicolumn{2}{|c|}{ Factors } & After 10 Days & After 20 Days & After 30 Days \\
\hline \multirow{4}{*}{ Cultivars } & Naxos & $1.86 \pm 0.001 \mathrm{a}$ & $3.22 \pm 0.003 b$ & $3.70 \pm 0.001 \mathrm{c}$ \\
\hline & Monaco & $0.71 \pm 0.002 \mathrm{~d}$ & $2.56 \pm 0.001 c$ & $3.12 \pm 0.002 \mathrm{~d}$ \\
\hline & Vicario & $1.46 \pm 0.001 \mathrm{c}$ & $3.41 \pm 0.004 \mathrm{a}$ & $4.02 \pm 0.002 \mathrm{a}$ \\
\hline & Bay Meadows & $1.61 \pm 0.001 \mathrm{~b}$ & $3.40 \pm 0.002 \mathrm{a}$ & $3.88 \pm 0.001 b$ \\
\hline \multirow{2}{*}{$\begin{array}{c}\text { Storage } \\
\text { technology }\end{array}$} & NSF & $1.80 \pm 0.002 \mathrm{~A}$ & $3.77 \pm 0.001 \mathrm{~A}$ & $4.36 \pm 0.003 \mathrm{~A}$ \\
\hline & $\mathrm{SF}$ & $1.02 \pm 0.001 \mathrm{~B}$ & $2.53 \pm 0.001 \mathrm{~B}$ & $3.01 \pm 0.001 \mathrm{~B}$ \\
\hline \multicolumn{2}{|c|}{ Mean } & 1.41 & 3.15 & 3.68 \\
\hline \multicolumn{2}{|c|}{$\begin{array}{c}\text { LSD } p \leq 0.05 \text { Interaction } \\
\text { Cultivar/storage technology }\end{array}$} & 0.007 & 0.008 & 0.103 \\
\hline
\end{tabular}

a, b, c, d, A, B. Means noted with the same letter in column are not significantly different $(p<0.05)$. NSF-without SmartFresh, SF-SmartFresh applied, LSD-least significant difference.

A significantly higher $(p \leq 0.05)$ fresh weight loss was recorded in broccoli not treated with 1-MCP, on average 43.3 percentage points higher after 10 days, 32.9 percentage points after 20 days of storage and 30.9 percentage points after 30 days of storage (Table 2). Significant interactions $(p \leq 0.05)$ between the cultivars and the use of 1-methylcyclopropene were also reported. The best results after the application of 1-MCP were recorded for the 'Monaco' cultivar, where the losses after 30 days of storage accounted only for $2.63 \%$ of the broccoli weight (Table 2).

The storage technology significantly modified the dry weight content in broccoli, after 10, 20 and 30 days of storage (Figure 1, Table 3). The application of the SmartFresh treatment significantly reduced the dry weight losses after storage. The greatest losses were recorded in 'Vicario', which was not treated with 1-MCP after harvest (Table 3). The smallest changes in terms of dry weight content during storage were noted in 'Naxos' and 'Bay Meadows'.

'Monaco' demonstrated the highest number of total sugars $\left(37.5 \mathrm{~g} \cdot \mathrm{kg}^{-1}\right.$ of fresh weight), and 'Vicario' had the least significantly: $30.7 \mathrm{~g} \cdot \mathrm{kg}^{-1}$ of fresh weight (Figure 2), while the content of reducing sugars was significantly the highest in 'Bay Meadows', $33.3 \mathrm{~g} \cdot \mathrm{kg}^{-1}$, and was significantly the lowest in 'Vicario', $25.5 \mathrm{~g} \cdot \mathrm{kg}^{-1}$ (Figure 3). Both the storage technology and genetic conditions contributed to the reduction in total sugars in broccoli, on average by $25 \%$ after 30 days of storage, and to a lesser extent with the use of 1-methylcyclopropene (21.8\%) (Table 4$)$. On the other hand, the content of reducing 
sugars increased on average by $18.0 \%$ (Table 5 ), and to a lesser extent in broccoli treated with 1-MCP.

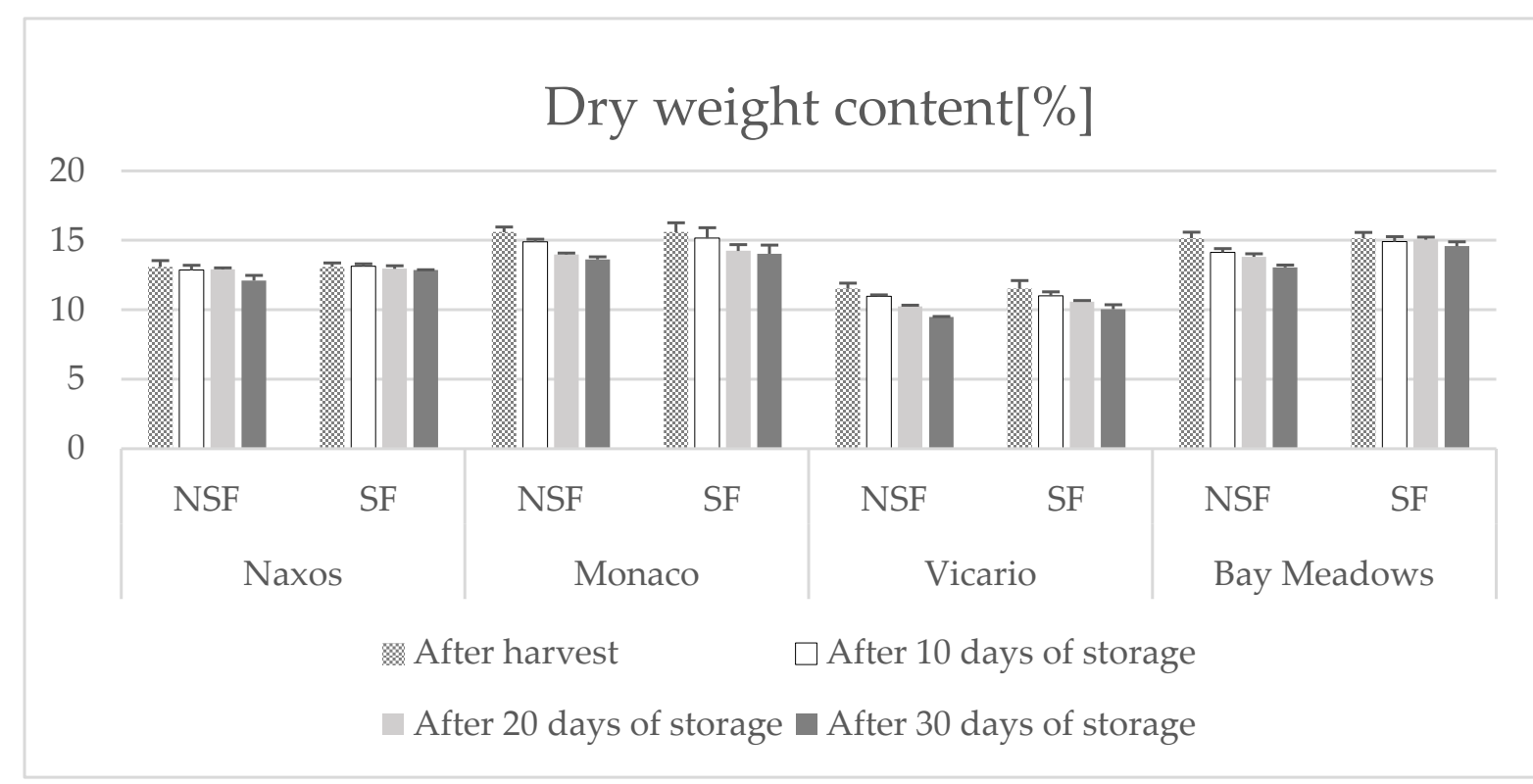

\begin{tabular}{lcccc}
\hline Factors & After & \multicolumn{3}{c}{ After 10 Days After 20 Days After 30 Days of } \\
& Harvest & of Storage & of Storage & Storage \\
\hline Cultivar & $*$ & $*$ & $*$ & $*$ \\
Storage technology NSF/SF & - & $*$ & $*$ & $*$ \\
Cultivar/storage technology & - & $*$ & $*$ & $*$ \\
\hline *-significant difference $p \leq 0.05$. NFS- without SmartFresh, SF-SmartFresh applied, mean for \\
3 replications.
\end{tabular}

Figure 1. Dry weight content $\left(\mathrm{g} \cdot \mathrm{kg}^{-1}\right.$ of fresh weight) in broccoli as an effect of the interaction between 1-MCP treatment and the cultivar after harvest, after 10, 20 and 30 days of storage.

Table 3. Difference in the dry weight content after harvest and after 10, 20, 30 days of storage depending on the cultivar and storage technology.

\begin{tabular}{|c|c|c|c|c|c|c|}
\hline \multirow{3}{*}{ Cultivar } & \multicolumn{6}{|c|}{ Difference (Score \%) ** } \\
\hline & \multicolumn{2}{|c|}{ After 10 Days of Storage } & \multicolumn{2}{|c|}{ After 20 Days of Storage } & \multicolumn{2}{|c|}{ After 30 Days of Storage } \\
\hline & NSF & SF & NSF & SF & NSF & SF \\
\hline Naxos & -1.9 & -0.4 & -1.5 & -1.6 & -7.6 & -2.3 \\
\hline Monaco & -5.6 & -1.7 & -11.3 & -7.6 & -13.9 & -9.0 \\
\hline Vicario & -5.9 & -3.2 & -12.4 & -6.8 & -19.1 & -11.5 \\
\hline $\begin{array}{c}\text { Bay } \\
\text { Meadows }\end{array}$ & -7.1 & -1.2 & -9.1 & -0.3 & -14.3 & -3.4 \\
\hline Means & -5.1 & -1.6 & -8.6 & -4.1 & -13.7 & -6.5 \\
\hline
\end{tabular}

In our own research, both the genetic factor and the storage technology significantly modified the content of vitamin C in broccoli (Figure 4, Table 6). The significantly highest content immediately after harvest was found in 'Monaco', $127.8 \mathrm{mg} \cdot \mathrm{kg}^{-1}$ of fresh weight, and the lowest content in 'Bay Meadows', $100.66 \mathrm{mg} \cdot \mathrm{kg}^{-1}$ of fresh weight. The greatest loss, over $48 \%$, was recorded in 'Vicario', which was not treated with 1-MCP after harvest, 
on average $48.2 \%$. On the other hand, in the trials with SmartFresh technology, the losses were reduced by half.

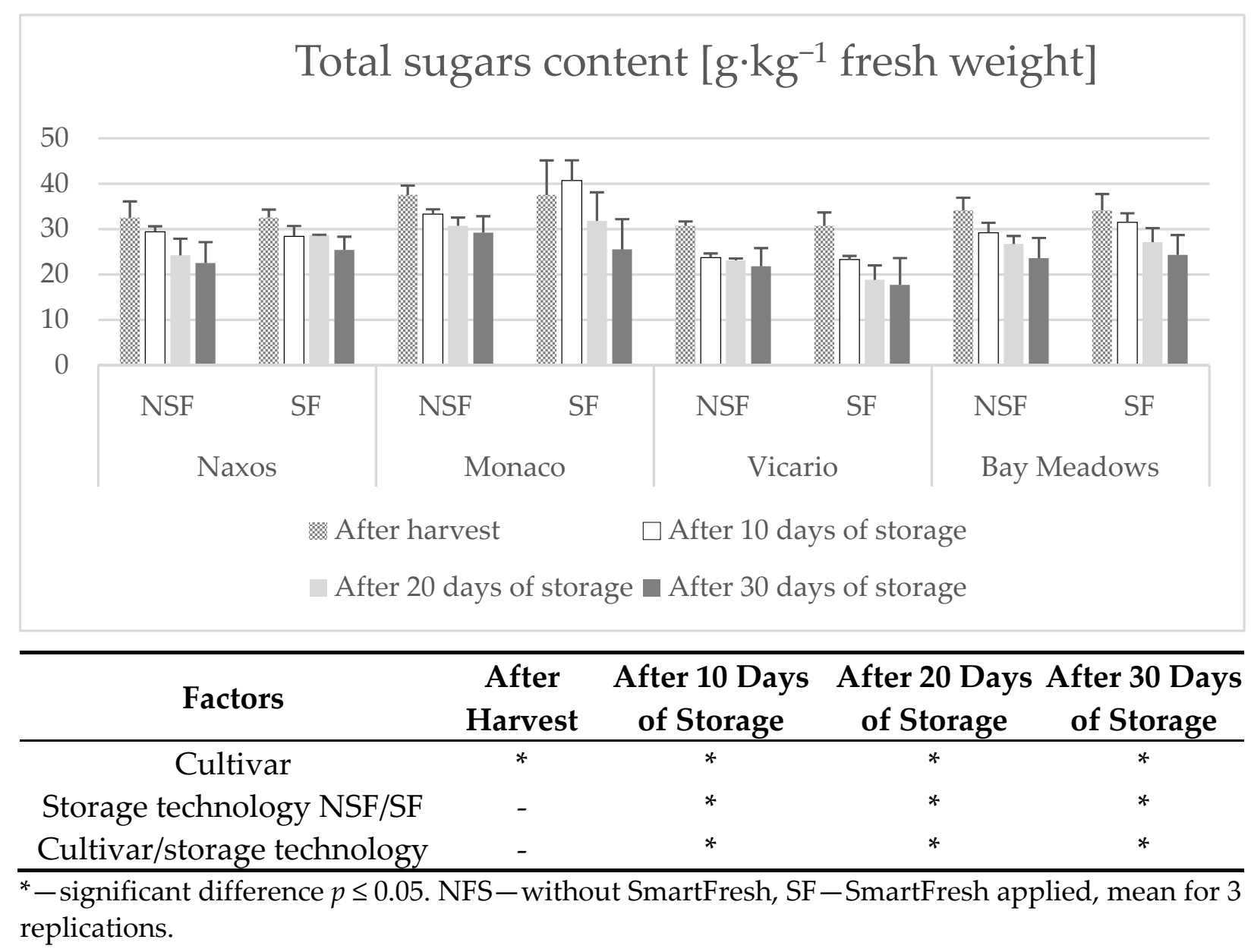

Figure 2. Total sugars ( $\mathrm{g} \cdot \mathrm{kg}^{-1}$ of fresh weight) in broccoli as an effect of the interaction between 1-MCP treatment and the cultivar after harvest, after 10, 20 and 30 days of storage.

Table 4. Difference of total sugars content after harvest and after 10, 20, 30 days of storage depending on the cultivar and storage technology.

\begin{tabular}{ccccccc}
\hline & \multicolumn{5}{c}{ Difference (Score \%) } \\
\cline { 2 - 7 } Cultivar & After 10 Days of Storage & After 20 Days of Storage & After 30 Days of Storage \\
\cline { 2 - 7 } & NSF & SF & NSF & SF & NSF & SF \\
\hline Naxos & -9.5 & -12.6 & -25.5 & -12.0 & -30.8 & -21.8 \\
Monaco & -11.2 & +8.5 & -18.1 & -15.2 & -22.1 & -32.0 \\
Vicario & -22.8 & -24.1 & -24.8 & -18.8 & -29.0 & -22.3 \\
Bay & -14.4 & -7.6 & -21.7 & -20.5 & -30.8 & -28.7 \\
Meadows & -14.5 & -9.0 & -22.5 & -21.6 & -28.2 & -21.8 \\
Means & & & & &
\end{tabular}

The content of total protein in the samples of broccoli after harvest was $24.0-32.8 \mathrm{~g} \cdot \mathrm{kg}^{-1}$ in terms of fresh weight; it was significantly the highest in 'Vicario' and significantly the lowest in 'Monaco' (Figure 5). After storage, the losses were small, especially in the samples treated with 1-MCP after harvest, $(3.7 \%)$, while in the untreated samples, the losses accounted for $10.6 \%$ (Table 7 ). 


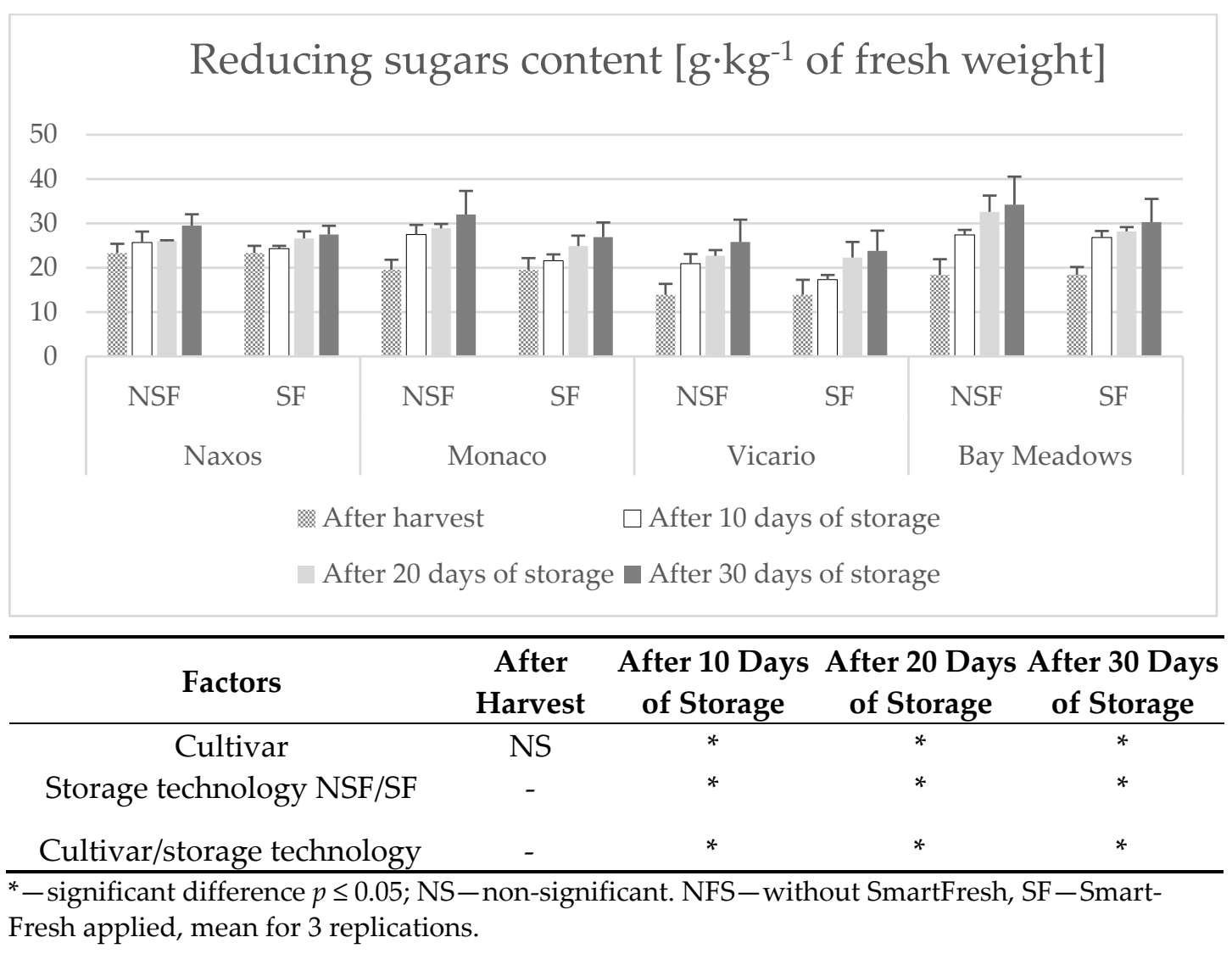

Figure 3. Reducing sugars ( $\mathrm{g} \cdot \mathrm{kg}^{-1}$ of fresh weight) of broccoli as an effect of the interaction between 1-MCP treatment and cultivar after harvest, after 10, 20 and 30 days of storage.

Table 5. Difference of reducing sugars content after harvest and after 10, 20, 30 days of storage depending on the cultivar and storage technology.

\begin{tabular}{ccccccc}
\hline \multirow{2}{*}{ Cultivar } & \multicolumn{7}{c}{ Difference (Score \%) } \\
\cline { 2 - 7 } & After 10 Days of Storage & After 20 Days of Storage & After 30 Days of Storage \\
\cline { 2 - 7 } & NSF & SF & NSF & SF & NSF & SF \\
\hline Naxos & +9.3 & +4.1 & +10.4 & +12.4 & +21.0 & +16.5 \\
Monaco & +9.3 & +3.9 & +14.8 & +6.7 & +19.1 & +12.2 \\
Vicario & +12.6 & +2.8 & +16.8 & +9.2 & +21.9 & +15.2 \\
Bay & +5.2 & +2.1 & +14.8 & +8.9 & +24.0 & +13.6 \\
Meadows & +9.1 & +3.2 & +14.2 & +9.3 & +21.5 & +14.4 \\
Means & +9.1 & & & & &
\end{tabular}

Table 6. Difference of vitamin C content after harvest and after 10, 20, 30 days of storage depending on the cultivar and storage technology.

\begin{tabular}{ccccccc}
\hline \multirow{2}{*}{ Cultivar } & \multicolumn{5}{c}{ Difference (Score \%) } \\
\cline { 2 - 7 } & After 10 Days of Storage & After 20 Days of Storage & After 30 Days of Storage \\
\cline { 2 - 7 } & NSF & SF & NSF & SF & NSF & SF \\
\hline Naxos & -30.4 & -19.2 & -36.9 & -21.9 & -41.9 & -24.2 \\
Monaco & -17.3 & -12.8 & -30.2 & -19.9 & -41.1 & -22.7 \\
Vicario & -30.8 & -8.3 & -39.2 & -10.5 & -48.2 & -25.4 \\
Bay & -23.0 & -12.7 & -24.7 & -16.0 & -42.5 & -21.3 \\
Meadows & -25.4 & -13.3 & -32.8 & -17.1 & -43.4 & -21.2 \\
Means & -25 &
\end{tabular}




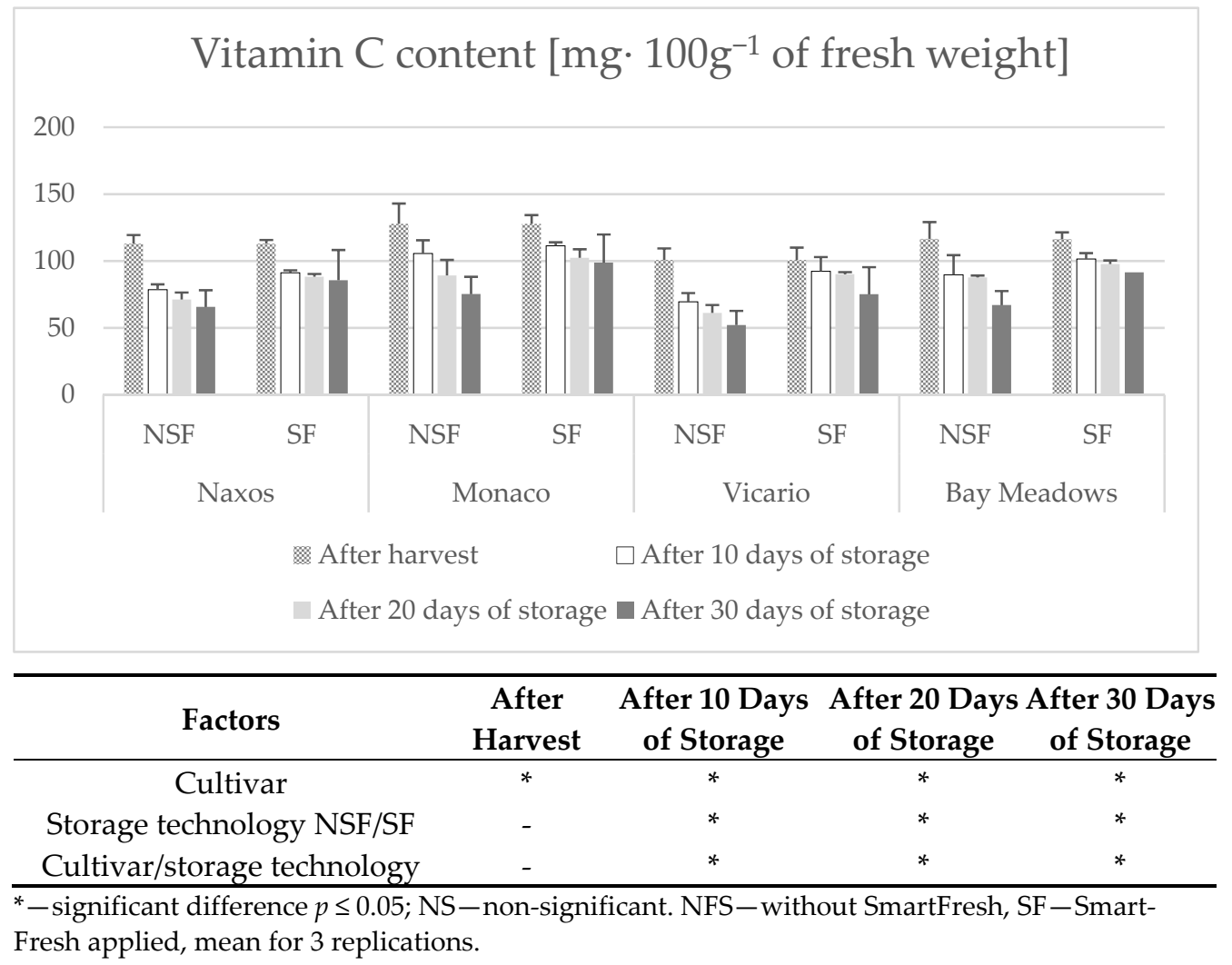

Figure 4. Vitamin C content ( $\mathrm{mg} \cdot \mathrm{kg}^{-1}$ of fresh weight) in broccoli as an effect of the interaction between 1-MCP treatment and the cultivar after harvest, after 10, 20 and 30 days of storage.

Table 7. Difference in crude protein content after harvest and after 10, 20, 30 days of storage depending on the cultivar and storage technology.

\begin{tabular}{ccccccc}
\hline \multirow{2}{*}{ Cultivar } & \multicolumn{5}{c}{ Difference (Score \%) } \\
\cline { 2 - 7 } & After 10 Days of Storage & After 20 Days of Storage & After 30 Days of Storage \\
\cline { 2 - 7 } & NSF & SF & NSF & SF & NSF & SF \\
\hline Naxos & -6.5 & -0.8 & -8.5 & -1.2 & -10.1 & -2.9 \\
Monaco & -1.1 & -1.0 & -4.9 & -3.5 & -10.4 & -4.8 \\
Vicario & -6.8 & -1.1 & -12.6 & -2.9 & -14.7 & -4.1 \\
Bay & -4.5 & -1.8 & -5.4 & -2.2 & -7.0 & -2.8 \\
Meadows & -4.7 & -1.2 & -7.9 & -2.5 & -10.6 & -3.7 \\
Means & -4.9 & & & & &
\end{tabular}

In the research, the content of nitrates $(\mathrm{V})$ in broccoli after harvest differed significantly across the cultivars and ranged from 144.3 in 'Naxos' to $214.3 \mathrm{~g} \cdot \mathrm{kg}^{-1}$ of fresh weight in 'Monaco' (Figure 6). The storage time reduced the content of nitrates (V) in broccoli, most in 'Naxos', by $16.2 \%$ (Table 8). This was due to an increase in the content of nitrites in that cultivar (Figure 7): in untreated samples by as much as 36.8\% (Table 9).

The results of the organoleptic evaluation of broccoli florets: color, compactness, rotting, taste and commercial value are presented in Figure 8. The 1-MCP used enhanced the tested features of the organoleptic value, while it did not differentiate the taste of broccoli florets. In our own research, the lowest compactness of the florets was recorded, and, thus, the lowest commercial value (basically unmarketable) for 'Naxos', 'Monaco' and 'Vicario' cultivars after 30 days of storage without the use of 1-MCP. However, thanks to the use of 1-MCP and low temperature $\left(4^{\circ} \mathrm{C}\right)$, the commercial value of those broccoli cultivars was satisfactory. 


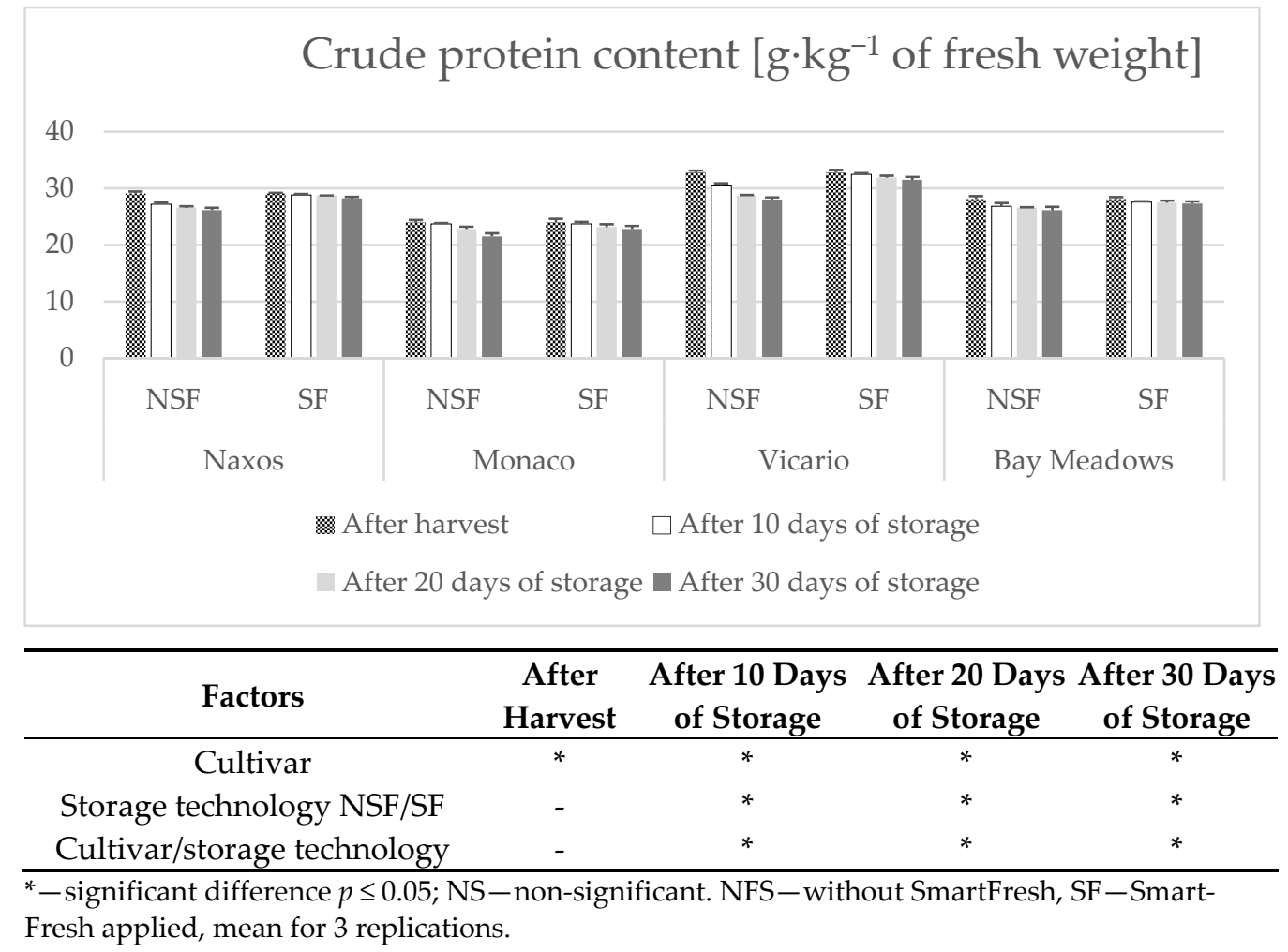

Figure 5. Crude protein ( $\mathrm{g} \cdot \mathrm{kg}^{-1}$ of fresh weight) in broccoli as an effect of the interaction between 1-MCP treatment and the cultivar after harvest, after 10, 20 and 30 days of storage.

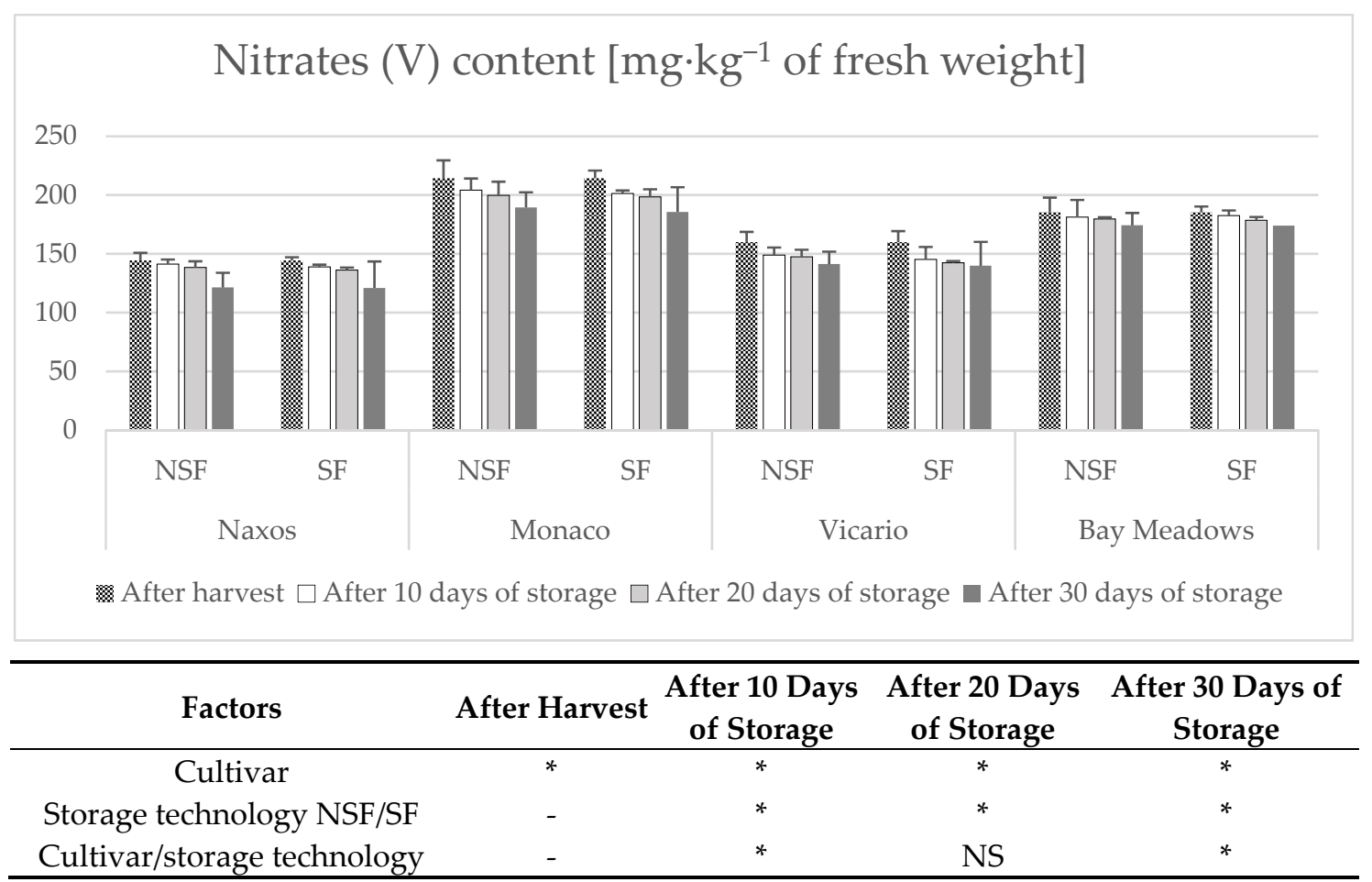

* - significant difference $p \leq 0.05$; NS-non-significant. NFS - without SmartFresh, SF-SmartFresh applied, mean for 3 replications.

Figure 6. Nitrates $(\mathrm{V})$ content $\left(\mathrm{g} \cdot \mathrm{kg}^{-1}\right.$ of fresh weight) in broccoli as an effect of the interaction between 1-MCP treatment and the cultivar after harvest, after 10, 20 and 30 days of storage. 
Table 8. Difference of nitrates (V) content after harvest and after 10, 20, 30 days of storage depending on the cultivar and storage technology.

\begin{tabular}{ccccccc}
\hline & \multicolumn{6}{c}{ Difference (Score \%) } \\
\cline { 2 - 7 } Cultivar & After 10 Days of Storage & \multicolumn{2}{c}{ After 20 Days of Storage } & \multicolumn{2}{c}{ After 30 Days of Storage } \\
\cline { 2 - 7 } & NSF & SF & NSF & SF & NSF & SF \\
\hline Naxos & -2.1 & -3.7 & -4.1 & -5.6 & -15.9 & -16.2 \\
Monaco & -4.7 & -6.1 & -6.8 & -7.4 & -11.6 & -13.4 \\
Vicario & -6.9 & -9.2 & -7.8 & -11.0 & -11.7 & -12.6 \\
Bay & -2.2 & -1.5 & 3.0 & -3.6 & -5.9 & -6.1 \\
Meadows & -4.0 & -5.1 & -5.4 & -6.9 & -11.3 & -12.1 \\
Means & -4.1 & & & & &
\end{tabular}

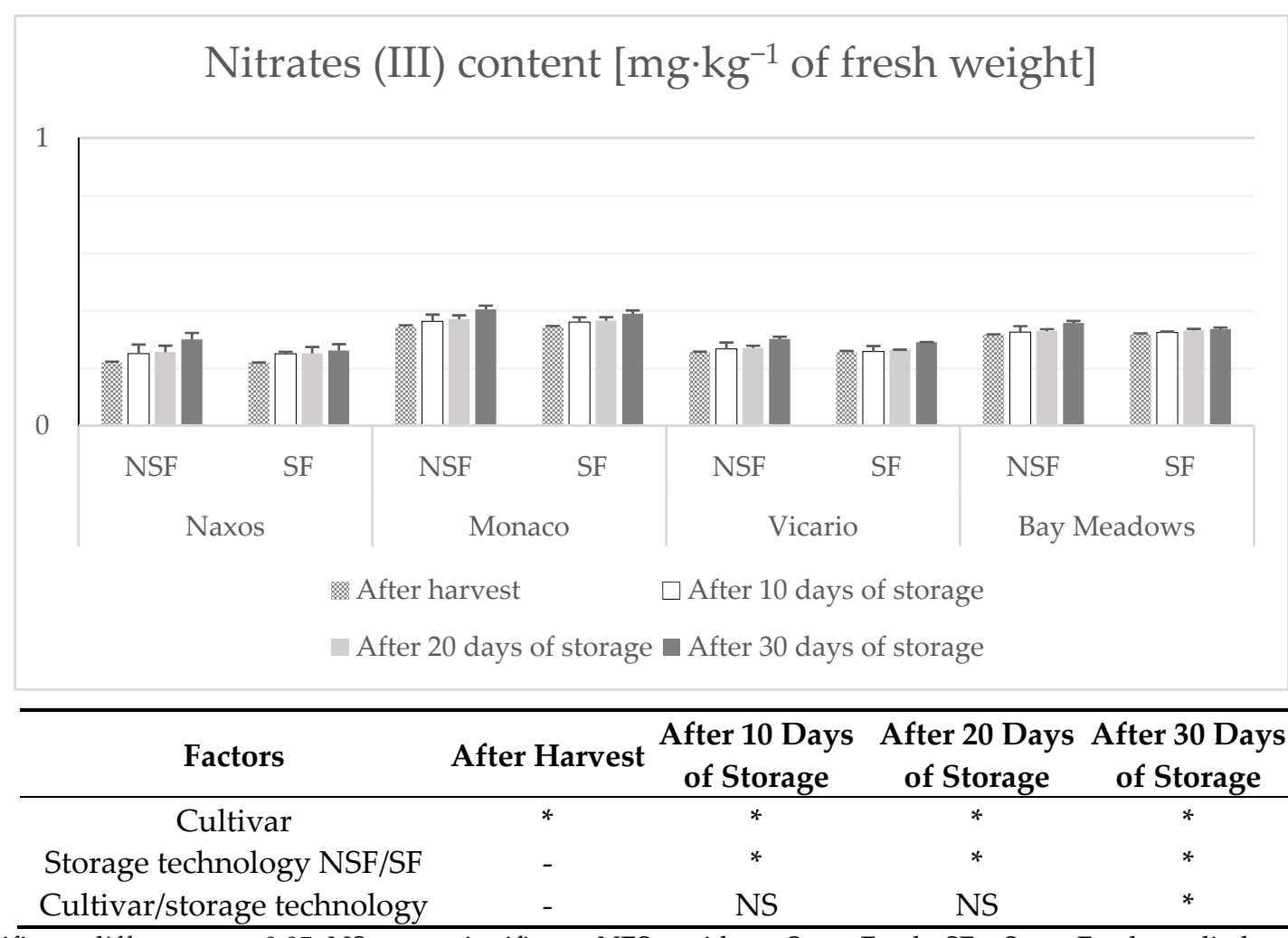

* - significant difference $p \leq 0.05$; NS-non-significant. NFS- without SmartFresh, SF-SmartFresh applied, mean for 3 replications.

Figure 7. Nitrates (III) content ( $\mathrm{g} \cdot \mathrm{kg}^{-1}$ of fresh weight) in broccoli as an effect of the interaction between 1-MCP treatment and the cultivar after harvest, after 10, 20 and 30 days of storage.

Table 9. Difference of nitrates (V) content after harvest and after 10, 20, 30 days of storage depending on the cultivar and storage technology.

\begin{tabular}{ccccccc}
\hline & \multicolumn{5}{c}{ Difference (Score \%) } \\
\cline { 2 - 7 } Cultivar & After 10 Days of Storage & After 20 Days of Storage & After 30 Days of Storage \\
\cline { 2 - 7 } & NSF & SF & NSF & SF & NSF & SF \\
\hline Naxos & +14.4 & +14.2 & +16.7 & +14.9 & +36.8 & +19.4 \\
Monaco & +5.5 & +4.9 & +7.8 & +6.4 & +17.6 & +13.3 \\
Vicario & +4.5 & +0.7 & +5.5 & +2.7 & +17.6 & +13.1 \\
Bay & +3.1 & +2.4 & +4.0 & +4.7 & +13.0 & +6.2 \\
Meadows & +6.9 & +5.6 & +8.5 & +7.2 & +21.3 & +13.0 \\
Means & + & & & & & \\
\hline
\end{tabular}




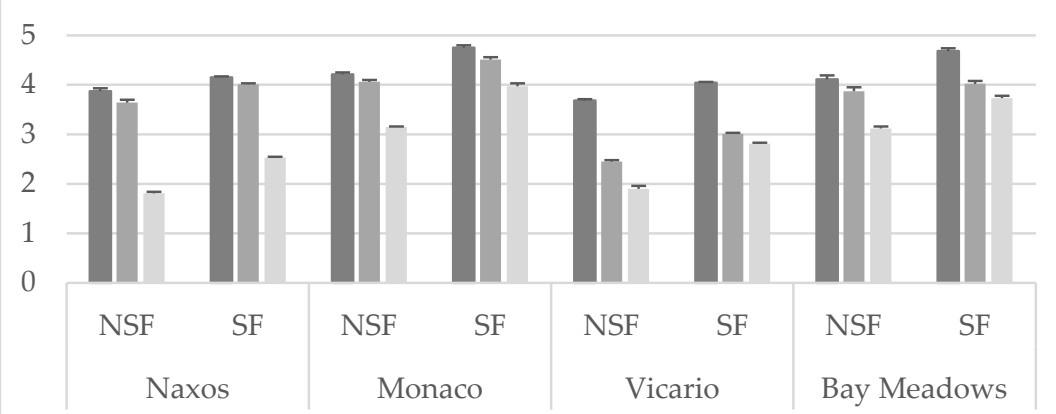

After 10 days $\square$ After 20 days After 30 days

(a) Color: 5-dark green, 4-green with a slight lightening, 3-green-yellow, 2-medium yellow, 1-strongly pale with yellowing and browning.

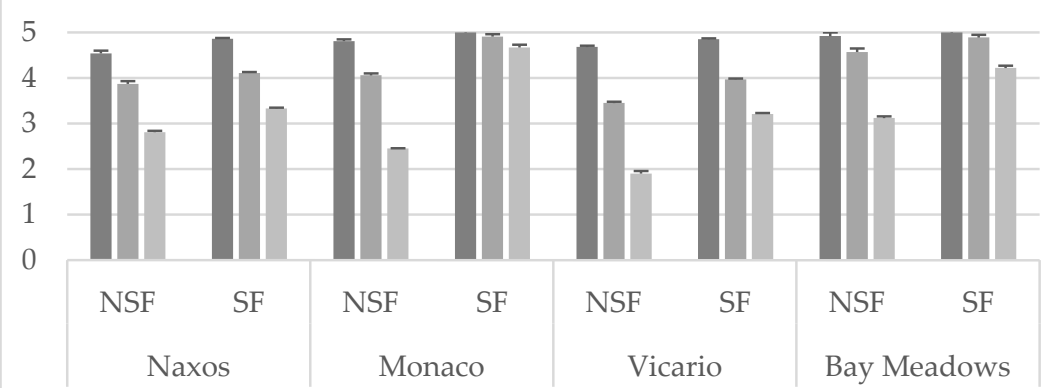

After 10 days After 20 days After 30 days

(b) Compactness: 5-very compact florets, 4-slight loss of compactness, 3-visible loss of compactness, 2-medium loose, 1-very loose.

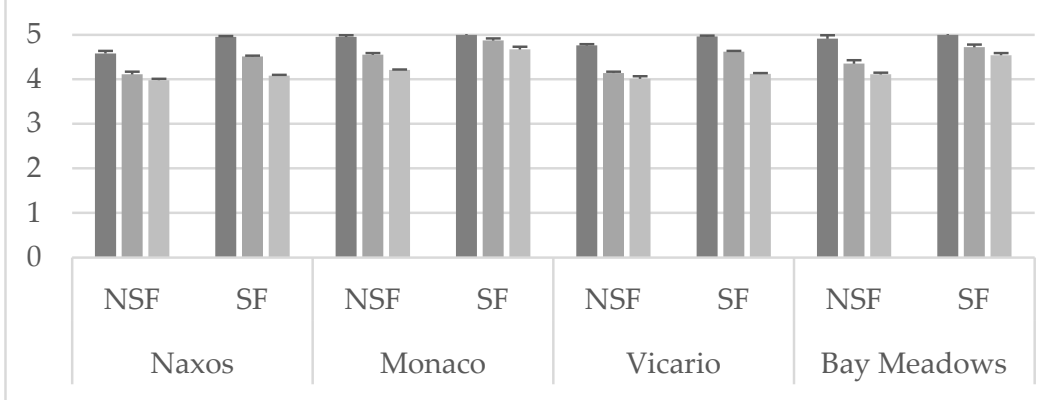

after 10 days After 20 days After 30 days

(c) Rotting: 5-4-no rotting, 3-small rot spots, 2-quite strong rotting, 1-heavy rotting.

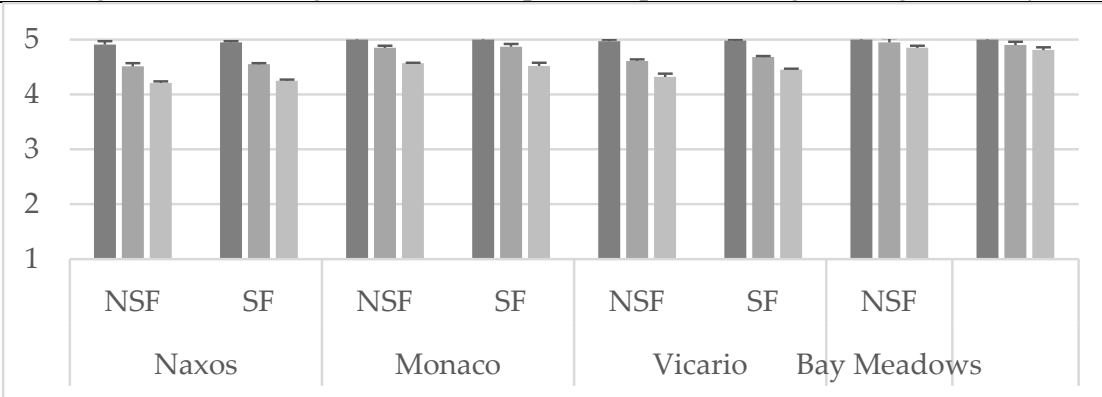

—After 10 days $\square$ After 20 days $\square$ After 30 days

(d) Taste: 5-excellent, unchanged, 4-good, 3-satisfactory, 2-poor, 1-bad, foreign taste.

Figure 8. Cont. 


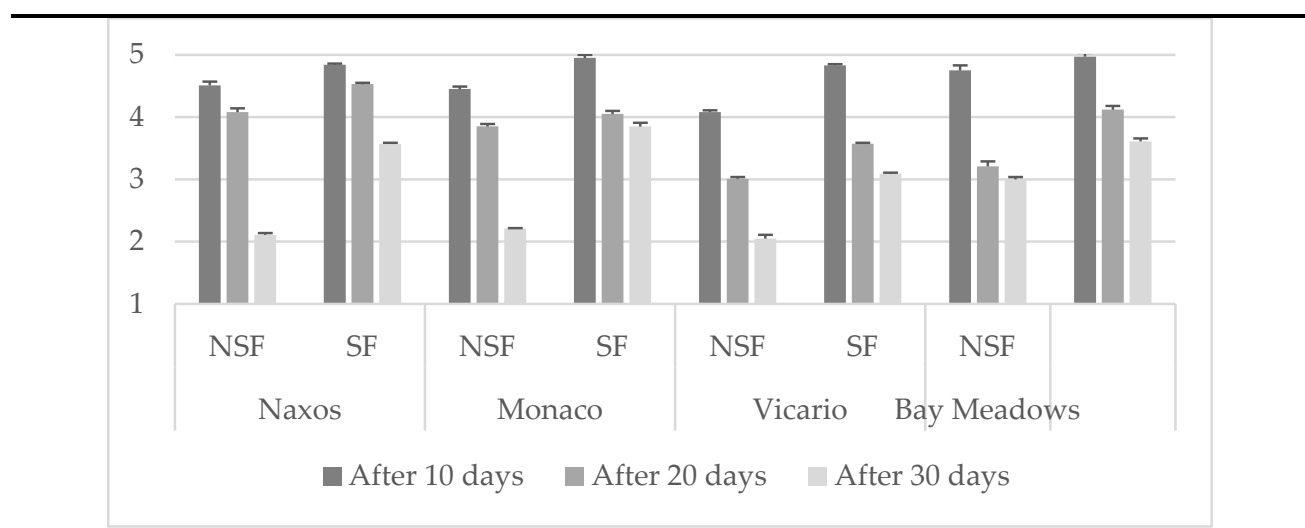

(e) Commercial value Commercial value: 5-excellent, florets like freshly harvested, 4good, 3-satisfactory, 2-poor, 1-bad

\begin{tabular}{|c|c|c|c|c|}
\hline Attribute & Factors & $\begin{array}{c}\text { After } 10 \text { Days of } \\
\text { Storage }\end{array}$ & $\begin{array}{c}\text { After } 20 \text { Days of } \\
\text { Storage }\end{array}$ & $\begin{array}{c}\text { After } 30 \text { Days of } \\
\text { Storage }\end{array}$ \\
\hline \multirow[t]{3}{*}{ Colour } & Cultivar & $*$ & * & ** \\
\hline & Storage technology NSF/SF & * & ** & $* *$ \\
\hline & Cultivar/storage technology & * & ** & ** \\
\hline \multirow[t]{3}{*}{ Compactness } & Cultivar & * & * & ** \\
\hline & Storage technology NSF/SF & * & * & $* *$ \\
\hline & Cultivar/storage technology & * & $* *$ & ** \\
\hline \multirow[t]{3}{*}{ Rotting } & Cultivar & * & * & $* *$ \\
\hline & Storage technology NSF/SF & * & * & $* *$ \\
\hline & Cultivar/storage technology & ** & ** & $* *$ \\
\hline \multirow[t]{3}{*}{ Taste } & Cultivar & * & * & * \\
\hline & Storage technology NSF/SF & NS & NS & * \\
\hline & Cultivar/storage technology & * & * & $* *$ \\
\hline \multirow[t]{3}{*}{ Commercial value } & Cultivar & * & $*$ & $* *$ \\
\hline & Storage technology NSF/SF & * & $*$ & $* *$ \\
\hline & Cultivar/storage technology & * & $* *$ & $* *$ \\
\hline
\end{tabular}

Explanation: ${ }^{*}$ significant differences $(p \leq 0.05) ;{ }^{* *}$ significant differences $(p \leq 0.01)$; NS-non-significant.

Figure 8. Organoleptic assessment according to the UNECE STANDARD FFV-48 [35] and own scoring (explanation as above).

\section{Discussion}

Broccoli is a very valuable vegetable due to its taste and being rich in precious nutrients, especially when consumed fresh and, thus, showing a number of health properties [27].

In the broccoli cultivars selected for the study, stored in conditions of reduced temperature to $4{ }^{\circ} \mathrm{C}$ and $95 \%$ relative air humidity, regardless of the treatment applied with the use of 1-MCP and the cultivars, weight loss was noted, on average, accounting for $1.41 \%$ after 10 days, $3.15 \%$ after 20 days and $3.68 \%$ after 30 days. Therefore, it is recommended to store the broccoli florets at a temperature of $0-1{ }^{\circ} \mathrm{C}$ and a relative air humidity of 90-95\% [37]. Although such conditions do not stop unfavorable quality changes, they significantly slow them down and extend the shelf life of broccoli [38]. The weight losses presented in this study are relatively small as compared to the losses at room temperature, which coincides with the results of the studies by Zsom P. et al. [39], demonstrating a positive effect of low temperature $\left(5^{\circ} \mathrm{C}\right)$, as compared to the weight loss results of broccoli stored at room temperature $\left(21^{\circ} \mathrm{C}\right)$. The causes of such changes are natural physicochemical processes that occur during storage, such as respiration, transpiration, water loss and changes in chemical composition, as well as pathogens. 
The results of our own research confirm the reports by Blankenship and Dole [40] and Watkins [26], proving the influence of 1-MCP on the inhibition of the physiological reactions of stored vegetables. After 10 days of storage, no signs of wilting, yellow discoloration or rotting were seen, especially in the 'Monaco' cultivar, after using 1-MCP. The differences in the loss scores, however, were significant in the trials treated with and without 1-MCP. After 20 days, the broccoli showed mild but visible signs of yellowing of the broccoli florets in which 1-MCP was not used, and the losses were greatest with the 'Vicario' and 'Bay Meadows' cultivars. On the other hand, in the further storage period, the symptoms of yellowing and loosening of the florets increased, and after 30 days they occurred with greater intensity in all the samples of broccoli cultivars not treated with 1-MCP. The best results with the use of 1-MCP were recorded for the 'Monaco' cultivar after 10, 20 and 30 days of storage, respectively, $0.71,2.56,3.12 \%$, and the greatest losses of fresh weight, especially after 20 and 30 days of storage, 3.41 and $4.02 \%$, respectively, and for 'Bay Meadows' after 20 days of storage (3.40\%). The research reported by those authors showed the positive effects of 1-MCP treatment in combination with a cold store to reduce the loss of natural broccoli mass. Moreover, these studies clearly show the positive effect on maintaining the quality after the combined use of 1-MCP and cold storage. Such conditions prevent or at least minimize the highly damaging effects of the gas ethylene (increased mass loss, chlorophyll breakdown caused yellowing, leaf and florets abscission). Even a $24 \mathrm{~h}$ long $2 \mathrm{ppm}$ ethylene treatment was not able to eliminate the effect of 1-MCP treatment $(24 \mathrm{~h}, 625 \mathrm{ppb})$ due to the complete and effective blockage of ethylene receptors during the 9 day period of cold storage at $5{ }^{\circ} \mathrm{C}$. It revealed an extremely positive effect of $1-\mathrm{MCP}$ due to its much greater binding affinity and binding to the active ethylene receptor than ethylene, resulting in a lower possibility of ethylene causing leaf cutting and increased respiration-related weight loss and deterioration.

The chemical composition of vegetables is genetically determined and also modified by factors affecting the plant during growth and storage [41]. In the authors' own research, the dry weight content was also cultivar-specific and it accounted for $11.52-15.59 \%$ after harvest. A similar content was reported by Grabowska et al. [42], and slightly lower results by Kosterna E. [43]. After harvest, the highest content was found in 'Monaco' and 'Bay Meadows' broccoli, while in 'Vicario' the content was lowest.

The weight loss was also related to the loss of dry mass after storage, which in our own research accounted for as much as 13.7 percentage points. The greatest losses were recorded in 'Vicario', which was not treated with 1-MCP after harvest.

The broccoli cultivars selected for the study differed significantly in terms of the nutrient content; it was similar to the values reported in other studies $[44,45]$. In our own research, changes during storage also occurred in the sugar content. The highest total sugar losses were recorded after 30 days of storage of broccoli not treated with 1-MCP in the 'Bay Meadows' and 'Naxos' cultivars (30.8\%). In turn, the content of reducing sugars increased by up to $24 \%$. The increase can be caused by a conversion of complex sugars during storage into simple sugars [29]. Sucrose is the main form of sugar transported to the sink tissues in sugar metabolism [46]. The accumulation of sucrose depends on the balance between its synthesis and degradation. In the study by Feng X. et al. [10], 1-MCP resulted in an induced higher activity of sucrose synthesis, the enzymes involved in sucrose biosynthesis and maintained a lower activity of sucrose synthase cleavage, the sucrose catabolizing enzyme, which may account for higher sucrose levels in 1-MCP-treated florets. Soluble acid invertase activity increased gradually in both the control and 1-MCP-treated broccoli florets during storage.

Broccoli is a product with high antioxidant content, especially ascorbic acid, carotenoids, phenols and flavonoids $[45,46]$. The vitamin C content in fresh broccoli ranges from 54 to $119.8 \mathrm{mg} / 100 \mathrm{~g}$ of DM. [47]. In the studies by Kwasniewska-Karolak I. and Mostowski R. [48], the loss of vitamin C was related to the natural processes that occur during the refrigerated storage of broccoli, i.e., respiration and transpiration, accounting for $24-26 \%$, which, according to Ma, G et al. [49], is, to a large extent, related to the genetic cultivar 
makeup. In our own research, both the genetic factor and the storage technology significantly modified the content of vitamin $C$ in broccoli. Significantly, the highest content immediately after harvest was found in 'Monaco', $127.8 \mathrm{mg} \cdot \mathrm{kg}^{-1}$ of fresh weight, and the lowest content in 'Bay Meadows', $100.66 \mathrm{mg} \cdot \mathrm{kg}^{-1}$ of fresh weight. The greatest loss, on average $48.2 \%$, was recorded in 'Vicario', which was not treated with 1-MCP after harvest. On the other hand, in the trials with SmartFresh technology, the losses were reduced by half. In any case, the content of vitamin $C$ decreased in the same way in all samples during storage as aging progressed, as described in other studies [48,49]. The aging process involves the accumulation of active oxygen species and, consequently, a reduction in the content of antioxidants, especially ascorbic acid [50,51].

Broccoli is also a source of protein. In the studies reported by Mansour A. A. et al. [52], the protein content of fresh broccoli was higher than that of cauliflower: it was $33.03 \%$ of crude protein, as compared to cauliflower $(27.03 \%)$. In our own research, the content of total protein in the samples of broccoli after harvest was $24.0-32.8 \mathrm{~g} \cdot \mathrm{kg}^{-1}$ in terms of fresh weight; it was significantly highest in 'Vicario' and significantly lowest in 'Monaco'. After storage, the losses were small, especially in the samples treated with 1-MCP after harvest, $(3.7 \%)$, while in the untreated samples, the losses accounted for $10.6 \%$.

The main source of nitrates $(\mathrm{V})$ in a daily food ration are vegetables and their products, which provide over $90 \%$ of the total amount of these compounds. The results on the harmfulness of nitrates and nitrites in the human diet are inconclusive. Older reports by many authors report that they are harmful when transformed into toxic nitrites, which, in turn, can transform into nitrosamines, being precancerous compounds [53]. However, the potential relationship between nitrate intake and cancer in humans has not been substantiated [54]. Research from the last few years indicates that the consumption of green vegetables, especially those containing large amounts of nitrates and nitrites, may have positive effects as they translate into a reduction in the long-term risk of cardiovascular disease [55]. Emerging data suggest that the benefits of dietary nitrate on the cardiovascular system are partially exerted through the modulation of immune and inflammatory aspects [55]. The content of nitrates in vegetables highly depends on the genetic cultivar determinants and storage [56]. In the studies presented, the cultivar also had a significant effect on the accumulation of nitrates and nitrites in broccoli florets (from 144.3 in 'Naxos' to $214.3 \mathrm{~g} \cdot \mathrm{kg}^{-1}$ of fresh weight in 'Monaco').The storage time reduced the content of nitrates in broccoli, the most in 'Naxos', by $16.2 \%$. This was due to an increase in the content of nitrites in that cultivar: in untreated samples by as much as $36.8 \%$.

The scores above 4.00 may classify broccoli in quality Class I. The best results in terms of color, compactness and non-rotting were noted in the 'Monaco' cultivar, while 'Bay Meadows' demonstrated the best taste and commercial value; also, the 'Naxos' cultivar showed the best commercial value, especially after 10 and 20 days of storage. The green color of broccoli is an important commercial quality index. Degreening of broccoli after harvest occurs rapidly during storage, however, the treatment of broccoli with 1-MCP resulted in a delayed loss of green color and delayed onset of yellowing [57]. Our study supported the evidence that the treatment of broccoli florets with 1-MCP inhibited yellowing and sensory quality similar to the research by Fernández-León et al. [28]. In the studies reported by these authors, the use of 1-MCP reduced the loss of green color and chlorophyll pigments, however, only during cold storage, not during storage at $20^{\circ} \mathrm{C}$. The presence of yellow florets ends the commercial marketability of broccoli. Ideal maturity is based on head diameter, compactness and tightly closed florets. Overmature heads are characterized by open florets or enlarged florets on the verge of opening, resulting in a loose head.

According to Cefola et al. [58], treatment with 1-MCP significantly extended the shelf life, reducing post-harvest deterioration, delaying chlorophyll degradation and delaying visuaL.Loss and flowering, as was also the case with samples stored in the presence of exogenous ethylene. Untreated broccoli florets stored in the air or the air + ethylene showed a significant increase in ammonia content during storage, suggesting stressful storage 
conditions. The results indicate that treatment with 1-MCP can be a good candidate to extend the shelf life, to maintain visual quality and to reduce quality loss in broccoli flowers.

\section{Conclusions}

Based on the data presented, it can be concluded that broccoli is a valuable source of basic nutrients such as raw protein, carbohydrates and vitamin C. Of all the broccoli cultivars, 'Monaco' demonstrated the lowest weight loss during storage, and the highest content of dry weight, total sugars and vitamin $C$ both after harvest and after storage. The cultivar contained the highest contents of nitrates and nitrites, both after harvest and after storage; however, the differences, as compared with the other cultivars, were significant, yet relatively low. The treatment of vegetables with 1-MCP significantly reduced the loss of all the nutrients tested, as compared with the broccoli stored without the use of 1-MCP, as well as decreased the content of harmful nitrates and toxic nitrites. The ethylene released during storage accelerates the aging processes that causes the decomposition of nutrients and the growth of nitrates and nitrites, and the use of an ethylene release blocker significantly slows down this process. The use of 1-MCP, especially in the 'Monaco' cultivar, allowed the color and compactness to be retained and lowered the tendency to rotting even after a 30-day storage period. It is possible to extend broccoli's shelf life up to 2 weeks longer than under the conditions without 1-MCP. However, not all of the cultivars are suitable for longer storage and they react differently to 1-MCP. With that in mind, it is essential to check the cultivar-specific reaction to the treatments extending their shelf life.

Author Contributions: Conceptualization, D.W.; methodology, D.W.; validation, D.W., W.K. and T.K.; formal analysis, D.W., W.K. and T.K.; investigation, D.W., W.K. and T.K.; data curation, D.W., W.K., T.K., P.P. and A.L.; writing-original draft preparation, D.W., W.K., T.K., P.P. and A.L.; writingreview and editing, D.W., W.K., T.K., P.P. and A.L.; visualization, D.W., W.K., T.K., P.P. and A.L.; supervision, D.W.; project administration, D.W. All authors have read and agreed to the published version of the manuscript.

Funding: This research received no external funding.

Institutional Review Board Statement: Not applicable.

Informed Consent Statement: Not applicable.

Data Availability Statement: Not applicable.

Acknowledgments: Publication was carried out with the use of instruments bought in the framework of the program 'Development of Stage 2 of Regional Centre for Innovativeness' of the European Fund for Regional Development in the framework of the Regional Operation Programme of KuyavianPomeranian for 2007-2013, Bydgoszcz, Poland.

Conflicts of Interest: The authors declare no conflict of interest.

\section{References}

1. Kader, A. Fruit maturity ripening and quality relationships. Acta Hort. 1999, 485, 203-208. [CrossRef]

2. Tian, M.S.; Downs, C.G.; Lill, R.E.; King, G.A. A Role for Ethylene in the Yellowing of Broccoli after Harvest. J. Am. Soc. Hort. Sci. 1994, 119, 276-281. [CrossRef]

3. Costa, M.L.; Civello, P.M.; Chaves, A.R.; Martinez, G.A. Effect of hot air treatments on senescence and quality parameters of harvested broccoli (Brassica oleracea L. var Italica) heads. J. Sci. Food Agric. 2005, 85, 1154-1160. [CrossRef]

4. Food and Agriculture Organization of the United Nations. FAOSTAT Statistical Database. 2021. Available online: http: //www.fao.org/faostat/en/ (accessed on 11 October 2021).

5. Jones, R.; Faragher, J.; Winkler, S. A review of the influence of postharvest treatments on quality and glucosinolate content in broccoli (Brassica oleracea var. italica) heads. Postharvest Biol. Technol. 2006, 41, 1-8. [CrossRef]

6. Zhang, Z.; Nie, M.; Xiao, Y.; Zhu, L.; Gao, R.; Zhou, C.; Li, D.; Xu, Y.; Dai, Z. Positive effects of ultrasound pretreatment on the bioaccessibility and cellular uptake of bioactive compounds from broccoli: Effect on cell wall, cellular matrix and digesta. LWT 2021, 149. [CrossRef]

7. Zhang, S.; Ying, D.Y.; Cheng, L.J.; Bayrak, M.; Jegasothy, H.; Sanguansri, L.; Augustin, M.A. Sulforaphane in broccoli-based matrices: Effects of heat treatment and addition of oil. LWT 2020, 128. [CrossRef] 
8. Bochnak-Niedźwiecka, J.; Szymanowska, U.; Świeca, M. Studies on the development of vegetable-based powdered beverages -Effect of the composition and dispersing temperature on potential bioaccessibility of main low-molecular antioxidants and antioxidant properties. LWT 2020, 131. [CrossRef]

9. Kyere, E.O.; Popovich, D.G.; Palmer, J.; Wargent, J.J.; Fletcher, G.C.; Flint, S. Reduction of the attachment, survival and growth of L. monocytogenes on lettuce leaves by UV-C stress. LWT 2021, 145. [CrossRef]

10. Feng, X.; Hongfei, W.; Yuechang, T.; Shuanquan, D.; Xing, Q.; Xuehong Ch Yonghua, Z. Effect of 1-methylcyclopropene on senescence and sugar metabolism in harvested broccoli florets. Postharvest Biol. Technol. 2016, 116, 45-49.11.

11. Costa, L.; Millan Montano, Y.; Carrión, C.; Rolny, N.; Guiamet, J. Application of low intensity light pulses to delay postharvest senescence of Ocimum basilicum leaves. Postharvest Biol. Technol. 2013, 86, 181-191.12. [CrossRef]

12. Wang, Y.; Yang, C.; Chen, Y.; Lin, Y.; Shaw, J. Characterization of senescence-associated proteases in postharvest broccoli florets. Plant Physiol. Biochem. 2004, 42, 663-670. [CrossRef]

13. Nishikawa, F.; Kato, M.; Hyodo, H.; Ikoma, Y.; Sugiura, M.; Yano, M. Ascorbate metabolism in harvested broccoli. J. Exp. Botany 2003, 54, 2439-2448. [CrossRef]

14. Serrano, M.; Martinez-Romero, D.; Guillén, F.; Castillo, S.; Valero, D. Maintenance of broccoli quality and functional properties during cold storage as affected by modified atmosphere packaging. Postharvest Biol. Technol. 2006, 39, 61-68. [CrossRef]

15. Costa, M.; Vicente, A.; Civello, P.; Chaves, A.; Martínez, G. UV-C treatment delays postharvest senescence in broccoli florets. Postharvest Biol. Technol. 2006, 39, 204-210. [CrossRef]

16. Pérez-Balibrea, S.; García-Viguera, C.; Castillo, S.; Serrano, M.; Valero, D. Modified atmosphere packaging for broccoli sprouts affected by film permeability. Acta Hortic. 2015, 1071, 269-274. [CrossRef]

17. Aiamla-or, S.; Yamauchi, N.; Takino, S.; Shigyo, M. Effect of UV-A and UV-B irradiation on broccoli (Brassica oleracea L. Italica Group) floret yellowing during storage. Postharvest Biol. Technol. 2009, 54, 177-179. [CrossRef]

18. Gómez-Lobato, M.; Hasperué, J.; Civello, P.; Chaves, A.; Martínez, G. Effect of 1-MCP on the expression of chlorophyll degrading genes during senescence of broccoli (Brassica Oleracea L.). Sci. Hortic. 2012, 144, 208-211. [CrossRef]

19. Fan, X.; Mattheis, J.P. Yellowing of broccoli in storage is reduced by 1 methylcyclopropene. HortScience 2000, 35, 885-887. [CrossRef]

20. Vijay, P.; Rakesh, P. Technical information for use of 1-methylcyclopropene (1-MCP) on fruits and vegetables for extending their shelf-life. In Laboratory Manual on "Post-Harvest Physiology of Fruits and Flowers" Division of Plant Physiology; JARJ: New Delhi, India, 2010; pp. 59-64.

21. Pereira, M.E.C.; Sargent, S.A.; Sims, C.A.; Huber, D.J.; Moretti, C.L.; Crane, J.H. Aqueous 1-methylcyclopropene extends longevity and does not affect sensory acceptability of Guatemalan-West Indian hybrid avocado. HortTechnology 2013, 23, 468-473. [CrossRef]

22. Regulation (EC) No 396/2005 of the European Parliament and of the Council of 23 February 2005 on Maximum Residue Levels of Pesticides in or on Food and Feed of Plant and Animal Origin and Amending Council Directive 91/414/EECText with EEA Relevance. Available online: https:/ / eur-lex.europa.eu/legal-content/EN/ALL/?uri=CELEX\%3A32005R0396 (accessed on 21 October 2021).

23. Sisler, E.C.; Blankenship, S.M. Methods of Counteracting an Ethylene Response in Plants. U.S. Patent 5,518,988, 1996.

24. Sisler, E.C.; Serek, M. Compounds interacting with the ethylene receptor in plants. Plant Biol. 2003, 5, 473-480. [CrossRef]

25. Sisler, E.C.; Serek, M.; Dupille, E. Comparison of cyclopropene, 1- methylcyclopropene, and 3,3-dimethylcyclopropene as ethylene antagonists in plants. Plant Growth Regul. 1996, 18, 169-174. [CrossRef]

26. Watkins, C.B. The use of 1-methylcyclopropene (1-MCP) on fruits and vegetables. Biotechnol. Adv. 2006, 24, 389-409. [CrossRef]

27. Watkins, C.B.; Miller, W.B. A Summary of Physiological Processes or Disorders in Fruits, Vegetables and Ornamental Products that are Delayed or Decreased, Increased, or Unaffected by Application of 1- Methylcyclopropene (1-MCP). 2005. Available online: bhttp:/ / www.hort.cornell.edu/mcp/N) (accessed on 23 October 2021).

28. Fernández-León, M.F.; Fernández-León, A.M.; Lozano, M.; Ayuso, M.C.; González-Gómez, D. Different postharvest strategies to preserve broccoli quality during storage and shelf life: Controlled atmosphere and 1-MCP. Food Chem. 2013, 138, 564-573. [CrossRef] [PubMed]

29. Grzegorzewska, M. Storage of vegetables. Gard. Rap. 2015, 7, 14-18. (In Polish)

30. EAPR. Method of Assessment for Potatoes and Potato Products; European Association for Potato Research: Wageningen, The Netherlands, 1974; pp. 68-69.

31. Talburt, W.F.; Smith, O. Potato Processing; Van Nostrand Reinhold Co.: New York, NY, USA, 1987; pp. $371-474$.

32. Kapur, A.; Haskowić, A.; Čoprajanićijević, A.; Klepo, L.; Topčagić, A.; Tahirović, I.; Sofić, E. Spectrophotometric analysis of total ascorbic acid content in various fruits and vegetables. Bull. Chem. Technol. Bosnia Herzeg. 2012, 38, 39-42.

33. Sweeney, R.A.; Rexroad, P.R. Comparison of LECO FP-228 "nitrogen determinator" with AOAC copper catalyst Kjeldahl method for crude protein. J. Assoc. Off. Anal Chem. 1987, 70, 1028-1030. [CrossRef]

34. Baker, W.H.; Thompson, T.L. Determination of nitrate-nitrogen (NO3-N) in plant samples by selective ion electrode. In Plant Analysis Reference Procedures for the Southern Region of the United States- Southern Cooperative Series Bulletin \#368; The University of Georgia: Athens, GA, USA, 1992; pp. 23-26.

35. UNECE STANDARD. FFV-48 Standards Concerning the Marketing and Commercial Quality Control of Broccoli 2017 Edition; United Nations: New York, NY, USA; Geneva, Switzerland, 2017; pp. 1-8. 
36. PN-EN ISO 8586:2014-Sensory Analysis-General Guidelines for the Selection, Training and Monitoring of Selected Assessors and Sensory Evaluation Experts (English version); ISO: Geneva, Switzerland, 2014; pp. 1-42.

37. Gębczyński, P. Quantitative changes of selected chemical components in the freezing and freezing process of main and side broccoli florets. Acta Sci. Pol. Technol. Aliment. 2003, 2, 31-39.

38. Gajewski, M. Storage of Vegetables; SGGW: Warsaw, Poland, 2005; pp. 1-176.

39. Zsom, P.; Polgari, P.; Nguyen LP, L.; Hitka, G. Zsom-Muha V. Quality maintenance of broccoli by the use of1-MCP treatments. Prog. Agric. Eng. Sci. 2020, 16, 95. [CrossRef]

40. Blankenship, S.M.; Dole, J.M. 1-Methylcyclopropene: A review. Postharvest Biol. Technol. 2003, 28, 1-25. [CrossRef]

41. Lee, S.K.; Kader, A.A. Preharvest and postharvest factors influencing vitamin C content of horticultural crops. Postharvest Biol. Technol. 2000, 20, 207-220. [CrossRef]

42. Grabowska, A.; Kunicki, E.; Libik, A. The effects of different methods of cultivation and plant spacing on the chemical composition of broccoli heads. Folia Hortic. 2009, 21, 25-34. [CrossRef]

43. Kosterna, E. The yield and quality of broccoli grown under flat covers with soil mulching. Plant Soil Environ. 2014, 60, 228-233. [CrossRef]

44. Tan, D.K.Y.; Wearing, A.H.; Rickert, K.G.; Birch, C.J. Broccoli yield and quality can be determined by cultivar and temperature but not photoperiod in south-east Queensland. Aust. J. Exp. Agric. 2000, 39, 901-909. [CrossRef]

45. Nishikawa, N.; Kato, M.; Hyodo, H.; Ikoma, Y.; Sugiura, M.; Yano, M. Effect of sucrose on ascorbate level and expression of genes involved in the ascorbate biosynthesis and recycling pathway in harvested broccoli florets. J. Exp. Botany 2005, 56, 65-67. [CrossRef] [PubMed]

46. Duarte-Sierra, A.; Forney, C.; Michaud, D.; Angers, P.; Arul, J. Influence of hormetic heat treatment on quality and phytochemical compounds of broccoli florets during storage. Postharvest Biol. Technol. 2017, 128, 44-53. [CrossRef]

47. Raseetha, S.; Leong, S.; Burritt, D.; Oey, I. Understanding the degradation of ascorbic acid and glutathione in relation to the levels of oxidative stress biomarkers in broccoli (Brassica oleracea L. italica cv. Bellstar) during storage and mechanical processing. Food Chem. 2013, 138, 1360-1369. [CrossRef]

48. Kwasniewska-Karolak, I.; Mostowski, R. Influence of cultivation method and refrigerated storage on changes in vitamin $\mathrm{C}$ and chlorophyll content in sweet pepper and broccoli. Ferment. Fruit Veg. Ind. 2017, 61, 10. (In Polish)

49. Ma, G.; Zhang, L.C.; Kato, M.; Yamawaki, K.; Asai, T.; Nishikawa, F.; Ikoma, Y.; Matsumoto, H. Effect of 1-methylcyclopropene on the expression of genes for ascorbate metabolism in postharvest broccoli. Postharvest Biol. Technol. 2010, 58, 121-128. [CrossRef]

50. Ma, G.; Zhang, L.; Kato, M.; Yamawaki, K.; Asai, T.; Nishikawa, F.; Kamisako, T. Effect of electrostatic atomization on ascorbate metabolism in postharvest broccoli. Postharvest Biol. Technol. 2012, 74, 19-25. [CrossRef]

51. Ivanov, B. Role of ascorbic acid in photosynthesis. Biochemistry 2014, 79, 282-289. [CrossRef] [PubMed]

52. Mansour, A.A.; Elshima, N.M.; Shekib, L.A.; Sharara, M.S. Effect of Domestic Processing Methods on the Chemical Composition and Organoleptic Properties of Broccoli and Cauliflower. Am. J. Food Nutr. 2015, 3, 125-130.

53. Raubenheimer, K.; Bondonno, C.; Blekkenhorst, L.; Wagner, K.H.; Peake, J.M.; Neubauer, O. Effects of dietary nitrate on inflammation and immune function, and implications for cardiovascular health. Nutr. ReviewsVR 2019, 77, 584-599. [CrossRef]

54. Tannenbaum, S.R.; Sinskey, A.J.; Weisman, M.; Bishop, W. Nitrite in human saliva. Its possible relationship to nitrosamine formation. J. Natl. Cancer Inst. 1974, 53, 79-84.

55. Weitzberg, E.; Lundberg, J.O. Novel aspects of dietary nitrate and human health. Annu. Rev. Nutr. 2013, 33, 129-159. [CrossRef] [PubMed]

56. Wichrowska, D. The content of nitrate (V) in potato tubers storage in temperature $4{ }^{\circ}$ C. Polish J. Nat. Sc. 2007, 4, $121-127$.

57. Yuan, G.; Sun, B.; Yuan, J.; Wang, Q. Effect of 1-methylcyclopropene on shelf life, visual quality, antioxidant enzymes and health-promoting compounds in broccoli florets. Food Chem. 2010, 118, 774-781. [CrossRef]

58. Cefola, M.; Amodio, M.L.; Rinaldi, R.; Vanadia, S.; Colelli, G. Exposure to 1-methylcyclopropen (1-MCP) delays the effects of ethylene on fresh-cut broccoli raab (Brassica rapa L.). Postharvest Biol. Technol. 2010, 58, 29-35. [CrossRef] 